\title{
Electrogenerated Chemiluminescence Detection of Mercury(II) Ions Based on DNA Probe Labeled with Ruthenium Complex
}

\author{
Yaping LI \\ Department of Chemistry and Chemical Engineering, Ankang University, Ankang 725000, P. R. China
}

\begin{abstract}
A novel mercury(II) ion $\left(\mathrm{Hg}^{2+}\right)$ biosensor with electrogenerated chemiluminescence (ECL) detection using tris $\left(2,2^{\prime}\right.$-bipyridyl) ruthenium derivatives (ruthenium complex) as labeling was developed in the prescent work. One thymine (T)-rich single-strand DNA (ssDNA) labeled with a ruthenium complex was taken as an ECL probe. When the other T-rich capture ssDNA was self-assembled onto the surface of a gold electrode with a thiol group, and then hybridized with the ECL probe to form double-strand DNA (dsDNA) structures in the presence of $\mathrm{Hg}^{2+}$, a strong ECL response was electrochemically generated. The ECL intensity was linearly related to the concentration of $\mathrm{Hg}^{2+}$ in the range from $1.0 \times 10^{-6}$ to $1 \times 10^{-9} \mathrm{M}$ with a detection limit of $3.0 \times 10^{-10} \mathrm{M}$. The relative standard deviation was $4.1 \%$ at $1.0 \times 10^{-7} \mathrm{M} \mathrm{Hg}^{2+}(n=5)$. This work demonstrates that the combination of the strongly binding T-rich DNA to $\mathrm{Hg}^{2+}$ with the highly sensitive ECL technique to design an ECL $\mathrm{Hg}^{2+}$ biosensor is a great promising approach for the determination of metal ions.
\end{abstract}

(Received June 17, 2010; Accepted November 21, 2010; Published February 10, 2011)

\section{Introduction}

Mercury ion $\left(\mathrm{Hg}^{2+}\right)$ is an environmentally very important heavy metal ion because of its high toxicity. $\mathrm{Hg}^{2+}$ contamination is widespread and occurs through a variety of natural and anthropogenic sources, and it can be found in many products of daily life, such as paints, electronic equipment, and batteries. ${ }^{1,2}$ It is known that the microbial biomethylation of mercury ions leads to the accumulation of mercury in the human body through the food chain, which can cause serious and permanent brain damage and other chronic diseases. ${ }^{3,4}$ Therefore, the sensitive and selective detection of $\mathrm{Hg}^{2+}$ in aqueous media is of great concern in both environment and food monitoring, as well as clinical toxicology. Toward this goal, many current techniques, such as atomic absorption/emission spectroscopy, ${ }^{5,6}$ inductively coupled plasma mass spectrometry (ICP-MS), ${ }^{7}$ selective cold vapor atomic fluorescence spectrometry, ${ }^{8,9}$ electrochemical, ${ }^{10,11}$ optical sensing devices ${ }^{12,13}$ and spectrophotometric methods ${ }^{14-16}$ are available. However, these methods require either expensive and sophisticated instrumentation or complicated samplepreparation processes. An interesting phenomenon concerning the formation of thymine- $\mathrm{Hg}^{2+}$-thymine $\left(\mathrm{T}-\mathrm{Hg}^{2+}-\mathrm{T}\right)$ attracted the attention of researchers in more recent studies, and some new $\mathrm{Hg}^{2+}$ chemosensors based on $\mathrm{T}-\mathrm{Hg}^{2+}-\mathrm{T}$ have been reported.

These methods include colorimetric sensors based on the $\mathrm{Hg}^{2+}$-mediated aggregation of gold nanoparticles or $\mathrm{Hg}^{2+}$-promoted amplification of HRP-mimicking DNAzyme, and fluorescence probes based on $\mathrm{Hg}^{2+}$-modulated resonance energy transfer or the double-strand intercalation of fluorescent dyes or other correlative fluorescence technology. Electrochemical sensors based on ferrocene labled T-rich DNA or the reduction of $\mathrm{Hg}^{2+}$, followed by localized surface plasmon resonance
(LSPR) light-scattering detection based on $\mathrm{Hg}^{2+}$ induced aggregation of gold nanoparticles, have also been reported recently. ${ }^{17}$

Electrogenerated chemiluminescence (ECL), also known as electrochemiluminescence, has attracted considerable attention in the past few decades, and has become an important and valuable detection method in analytical chemistry ${ }^{18-23}$ for its many promising advantages, such as simplicity, high sensitivity, rapidity and easy controllability; it has been proved to be a useful technique in immunosensing, ${ }^{24}$ DNA hybridization assays and enzymatic biosensors. ${ }^{25}$ The combination of the high sensitive ECL technique with DNA has seldom been recorded in the literature. ${ }^{26-28}$ Bruno and $\mathrm{Kiel}^{26,27}$ reported an aptamermagnetic bead-ECL scheme for the detection of anthrax spores, ${ }^{26}$ cholera toxin ${ }^{27}$ and staphylococcal enterotoxin B. ${ }^{28}$ It is possible to design an alternative DNA-based biosensor using the ECL technique for the determination of metal ions. To our best knowledge, there is no report that an ECL DNA-based biosensor exists for the determination of $\mathrm{Hg}^{2+}$.

The aim of the present work is to develop a novel ECL DNA-based biosensor for the determination of metal ions. As a model system, $\mathrm{Hg}^{2+}$ was chosen as an analyte and T-rich DNA was taken as the molecular recognition element. In the absence of a target, the ECL probe is thought to remain unhybridized with the capture DNA, resulting in a blank ECL signal due to the absence of an ECL tag on the electrode surface. In the presence of a target, the ECL probe folds into a $\mathrm{Hg}^{2+}$-binding double-strand with the capture of DNA on the surface of the electrode and thus a strong ECL signal is generated due to the closeness of the tag to the electrode surface. The concentration of the analyte was quantified by the ECL signal of the ruthenium complex in the presence of tripropylamine (TPA). 


\section{Experimental}

\section{Materials}

$\mathrm{N}$-Hydroxysuccinimide (NHS), 4,4'-dicarboxylic acid-2,2'bipyridyl (dcbpy), 1-ethyl-3-(3-dimethylaminopropyl) carbodiimide (EDC), $N, N^{\prime}$-dicyclohexyl carbodiimide (DCC) and sodium hexafluorophosphate were purchased from Sigma (USA). Ruthenium(III) chloride hydrate was obtained from Acros Organics (Japan). 2,2'-Bipyridine, tri- $n$-propylamine (TPA) and ethylenediamine were obtained from First Reagent Company of Shanghai (Shanghai, China).

T-rich DNA1 and DNA2 were synthesized by Shanghai Sangon Biological Science \& Technology Company (Shanghai, China). Their sequences were: DNA1, 5'-SH ${ }_{2}$-AAGGGTGCT GCTCCT-3'; DNA2, 3'-NH ${ }_{2}$-TTCCCTCGTCGTGGT-5'.

An ss-DNA stock solution was prepared using water, and was kept at $-18^{\circ} \mathrm{C}$ in a refrigerator; $0.10 \mathrm{M}$ phosphate buffer solutions (PBS, pH 7.4) were used for the hybridization and wash solution. All other reagents were of analytical grade, and Millipore filtered water ( $>18 \Omega \mathrm{M} \mathrm{cm}^{-1}$ ) was used throughout.

\section{Apparatus}

ECL experiments were performed with a CHI660B Electrochemistry Working Station (CH Instruments Inc., Austin, TX). All experiments were carried out with a conventional three-electrode system. The working electrode was a gold electrode. A Pt wire was used as the counter electrode, and $\mathrm{Ag} / \mathrm{AgCl}$ (saturated $\mathrm{KCl}$ ) was used as a reference electrode, which was invariable during the experiment period. All of the potentials were measured and reported according to this reference electrode. The ECL intensity produced in the electrolytic cell was detected and recorded by a flow-injection chemiluminescence analyzer (IFFD, Xi'an Remax Electronic Science Tech. Co. Ltd., Xi' an, China), which was operated by a personal computer.

\section{Fabrication of ECL biosensors}

According to Refs. 29 - 31, ruthenium bis(2,2'-bipyridine) (2,2'-bipyridine-4,4'-dicarboxylic acid)- $N$-hydroxysuccinimide ester (ruthenium complex) was synthesized. The ECL probe, $\mathrm{Ru}(\mathrm{bpy})_{2}$ (dcbpy)-NHS-DNA2 (Ru-DNA2), was synthesized according to Ref. 32.

A bare gold electrode $(d=3.0 \mathrm{~mm})$ was polished with 1 , 0.3 and $0.05 \mu \mathrm{m}$ aluminum slurry on a polishing cloth, respectively, and sonicated in acetone and doubly distilled water thoroughly. The electrode was then cleaned by cycling between 0 and $1.5 \mathrm{~V}$ versus $\mathrm{SCE}$ in $\mathrm{H}_{2} \mathrm{SO}_{4}\left(0.5 \mathrm{~mol} \mathrm{~L}^{-1}\right)$ at a scan rate of $100 \mathrm{mV} \mathrm{s}^{-1}$ until reproducible cyclic voltammograms were obtained, and was characterized by cycling between -0.2 and $0.6 \mathrm{~V}$ versus $\mathrm{SCE}$ in $\mathrm{PBS}\left(0.1 \mathrm{~mol} \mathrm{~L}^{-1}, \mathrm{pH} 7.0\right)$ containing $\left[\mathrm{Fe}(\mathrm{CN})_{6}\right]^{3-}$ and $\left[\mathrm{Fe}(\mathrm{CN})_{6}\right]^{4-}(1: 1)$ at a scan rate of $100 \mathrm{mV} \mathrm{s}^{-1}$ until a well-shaped cyclic voltammogram with a peak-to-peak separation of $60-70 \mathrm{mV}$ was observed. ${ }^{25}$ The cleaned electrode was immersed in $500 \mu \mathrm{L}$ of a DNA1 solution with a desired concentration for $4 \mathrm{~h}$ at $37^{\circ} \mathrm{C}$ to immobilize the captured DNA on the surface of gold electrode through a self-assembly process, and was then washed twice with water to remove DNA, not bound to the gold electrode. The captured DNA immobilized electrode was then immersed in a $2 \mathrm{mM}$ mercaptohexanol solution for $30 \mathrm{~min}$ to cover the nonspecific sites. The resulting electrode was then immersed in $1.0 \mathrm{~mL}$ of a solution containing both the probe DNA and the sample for $30 \mathrm{~min}$ at $37^{\circ} \mathrm{C}$. After this, the electrode was thoroughly washed with the same buffer. It was then employed as the working electrode.
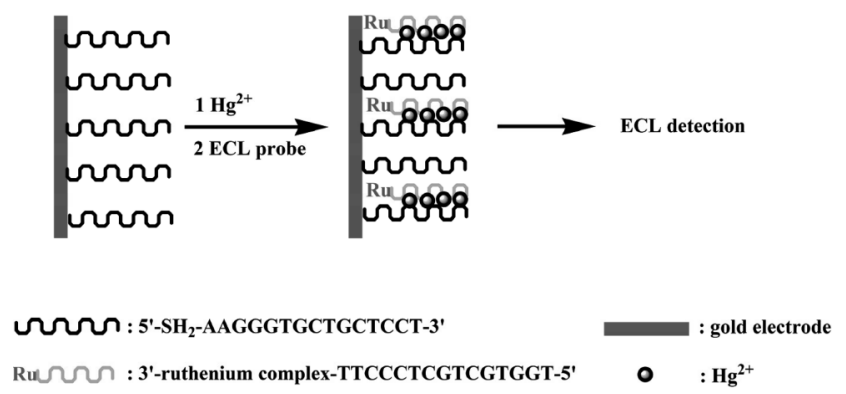

Scheme 1 Schematic diagram of the ECL biosensing method for the detection of $\mathrm{Hg}^{2+}$ using ECL of ruthenium complex tags.

\section{ECL measurement}

A three-electrode system composed of a biosensor or a disk gold electrode as a working electrode, a platinum plate as a counter electrode, and a $\mathrm{Ag} / \mathrm{AgCl}$ (saturated $\mathrm{KCl}$ ) as a reference electrode. The ECL measurement was performed at a constant potential of the $+0.90 \mathrm{~V}$ in $2.0 \mathrm{~mL}$ of $0.10 \mathrm{M}$ PBS containing $0.10 \mathrm{M}$ TPA. The concentration of target $\mathrm{Hg}^{2+}$ was quantified by the ECL intensity.

\section{Results and Discussion}

\section{Analytical principle of the ECL sensor}

The developed ECL sensor relies on the interaction between $\mathrm{T}$ and $\mathrm{Hg}^{2+}$ by a pair of T-rich DNAs, as shown in Scheme 1 . The sensor system comprises two strands of four pairs of T-T mismatches as the binding sites for $\mathrm{Hg}^{2+}$. One acts as the capture DNA immobilized on a gold electrode surface via self-assembly through the thiol anchor at the $5^{\prime}$-terminus. The other one acts as an ECL probe with a ruthenium complex at the 3 '-end. In the absence of $\mathrm{Hg}^{2+}$, the single-stranded DNA probe did not hybridize upon the capturing DNA due to the four pairs of T-T mismatches, and the ECL intensity was small. After the addition of $\mathrm{Hg}^{2+}$, the interaction between the capture DNA and the probe DNA became stronger due to the formation of $\mathrm{T}^{-} \mathrm{Hg}^{2+}-\mathrm{T}$. A strong ECL signal was produced due to the closeness of the ruthenium complex to the electrode surface. In order to confirm the function of SH-DNA, a bare gold electrode without captured DNA was also used as the working electrode in control experiments. There is nearly no ECL response from the bare gold electrode without the capture DNA. This validated that the SH-DNA acted as the capture DNA.

\section{Optimization of the experimental conditions}

In order to determine the optimal analytical parameters, the experimental conditions, such as the reaction medium, $\mathrm{pH}$ and electrochemical parameters were investigated.

Selection of the ECL reaction medium. Different media, including $\mathrm{Na}_{2} \mathrm{CO}_{3}-\mathrm{NaHCO}_{3}, \mathrm{KH}_{2} \mathrm{PO}_{4}-\mathrm{K}_{3} \mathrm{PO}_{4}, \mathrm{H}_{3} \mathrm{BO}_{3}-\mathrm{NaOH}$ and $\mathrm{KCl}-\mathrm{KOH}(0.1 \mathrm{M})$, were assessed to determine their influence on the ECL response. The experimental results suggested that the phosphate buffer solution $\left(\mathrm{KH}_{2} \mathrm{PO}_{4}-\mathrm{K}_{3} \mathrm{PO}_{4}, \mathrm{PBS}, \mathrm{pH} 7.4\right.$, $0.1 \mathrm{M}$ ) offered the best ECL sensing performances for $\mathrm{Hg}^{2+}$. Therefore, PBS was selected as the optimum ECL reaction medium for detecting $\mathrm{Hg}^{2+}$ in subsequent research work.

Effect of the $p H$ on the ECL intensity. The ECL reaction of the ruthenium complex was greatly influenced by the $\mathrm{pH}$ value of the solution. The ECL intensity increased from $\mathrm{pH} 6.6$ to 7.40 , and reached a maximum at $\mathrm{pH} 7.40$ (Fig. 1). Thus $\mathrm{pH} 7.40$ was 


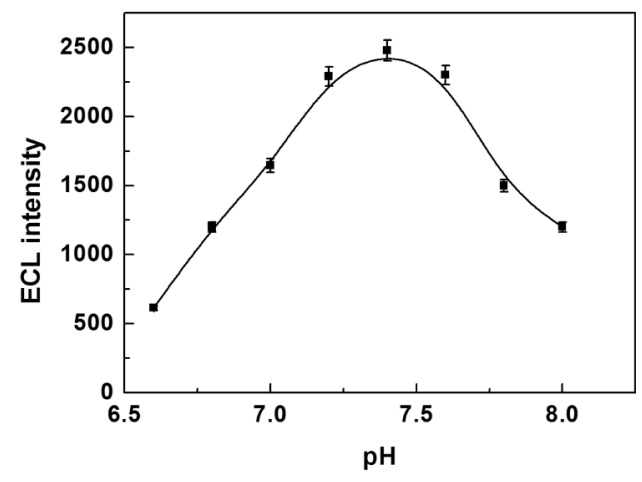

Fig. 1 Effect of $\mathrm{pH}$ on the ECL intensity.

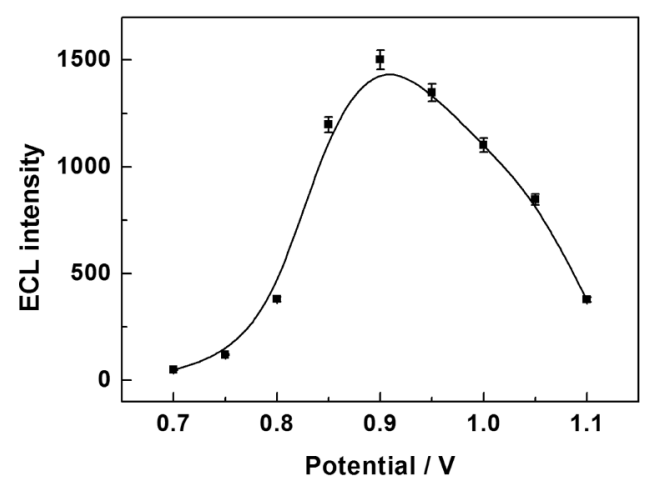

Fig. 2 Effect of the applied potential on the ECL intensity in $0.10 \mathrm{M}$ PBS (pH 7.40) containing 0.10 M TPA.

used in following experiments. Considering, moreover, the formation of $\mathrm{Hg}(\mathrm{OH})_{2}$ under too-high $\mathrm{pH}$ conditions, ${ }^{31} \mathrm{pH} 7.40$ was selected as the hybridization $\mathrm{pH}$.

Selection of electrochemical parameters. The electrochemical parameters would obviously affect the ECL emission intensity. Different types of electrochemical experiments were investigated in detail. An ECL signal was observed when a constant potential, linear sweep, cyclic voltammetry and normal pulse voltammetry were used. However, it was found that stronger and stable ECL intensity was obtained when a constant potential mode was employed. Therefore, this mode was chosen in the present work because of its high sensitivity. The effect of an applied potential on the ECL intensity was also investigated in detail. The maximum ECL values and good reproducibility were obtained at $+0.90 \mathrm{~V}$ (Fig. 2). Therefore, a constant potential of $+0.90 \mathrm{~V}$ was chosen in the following experiments. The presence of TPA made the oxidation current of $\mathrm{Ru}(\mathrm{bpy})_{3}{ }^{2+}$ increase clearly while the reduction current decreased, which is consistent with the electrocatalytic reaction mechanism.

The effect of the Ru-DNA2 concentration on the ECL intensity was also investigated. In this detection, Ru-DNA2 acts as the signal probe. The concentration of Ru-DNA2 seriously affects the ECL intensity (results not shown). We observed that the ECL intensity was significantly enhanced when the Ru-DNA2 increased from $0.01,0.03,0.06,0.10,0.30$ on 0.60 to $1.0 \mu \mathrm{mol} / \mathrm{L}$. However, at concentrations $>1.0 \mu \mathrm{mol} / \mathrm{L}$, further increases in the ECL intensity were very small. Thus $10 \mu \mathrm{mol} / \mathrm{mL} \mathrm{Ru}$ was used for further investigations.

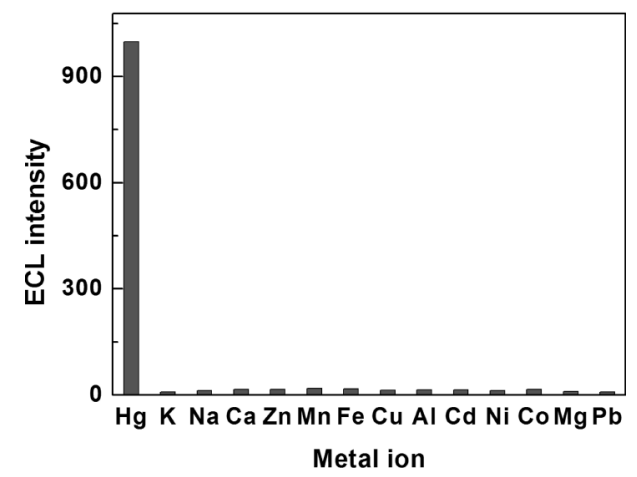

Fig. 3 Selectivity of the $\mathrm{Hg}^{2+}$ biosensor. All of the other metal ions were at $1 \times 10^{-5} \mathrm{M}$. The $1 \times 10^{-7} \mathrm{M} \mathrm{Hg}^{2+}$ was used.

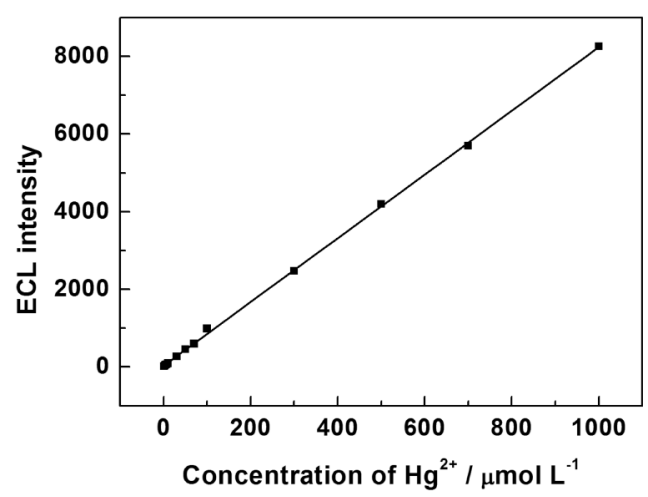

Fig. 4 Standard curve of the ECL intensities for $\mathrm{Hg}^{2+}$.

\section{Selectivity of ECL biosensor}

Evaluation of the selectivity of fabricated ECL biosensor was performed by examining several metal ions $\left(\mathrm{K}^{+}, \mathrm{Na}^{+}, \mathrm{Ca}^{2+}, \mathrm{Zn}^{2+}\right.$, $\left.\mathrm{Mn}^{2+}, \mathrm{Fe}^{3+}, \mathrm{Cu}^{2+}, \mathrm{Al}^{3+}, \mathrm{Cd}^{2+}, \mathrm{Ni}^{2+}, \mathrm{Co}^{2+}, \mathrm{Mg}^{2+}, \mathrm{Pb}^{2+}\right)$. The ECL intensity of the developed ECL biosensors was examined after immersing the ECL biosensors in $1 \times 10^{-7} \mathrm{M} \mathrm{Hg}^{2+}$ according to the protocol described in the ECL measurement section concerning the ECL measurement, respectively. A significant increase, induced by the interaction of the ECL biosensor with $\mathrm{Hg}^{2+}$, was observed. The other metal ions almost had no ECL signal produced, which indicated that the $\mathrm{Hg}^{2+}$ sensor was highly selective for $\mathrm{Hg}^{2+}$, indicating that the developed strategy has a sufficient selectivity, and that $\mathrm{Hg}^{2+}$ could be unequivocally identified (Fig. 3).

\section{Linear response range, detection limit and precision}

Under the selected conditions, a linear function for $\mathrm{Hg}^{2+}$ was achieved from $1.0 \times 10^{-6}$ to $1 \times 10^{-9} \mathrm{M}$ with the equation $I_{\mathrm{ECL}}=8.2069 C+35.21\left(I_{\mathrm{ECL}}\right.$ is the ECL intensity; $C$ is the concentration of $\left.\mathrm{Hg}^{2+}, \mathrm{nM} ; R^{2}=0.9996\right)$. A detection limit of $3.0 \times 10^{-10} \mathrm{M} \mathrm{Hg}^{2+}$ was estimated using $3 \sigma$ (Fig. 4). The relative standard deviation was $4.1 \%$ for detecting $1.0 \times 10^{-7} \mathrm{M} \mathrm{Hg}^{2+}$ $(n=5)$.

Other mismatch sequences of Ru-DNAs were used to optimize the ECL intensity. The experimental results suggested that the Ru-DNA sequence with four bp mismatches has a higher sensitivity. Thus in this method a DNA sequence with four bp mismatches of Ru-DNAs was used. If the sequences of DNA was too short, the formed duplex DNA would be unstable. But if the sequences of DNA were too long, there would require 
Table 1 Results of determination of $\mathrm{Hg}^{2+}$ in tap water

\begin{tabular}{ccrcc}
\hline Sample No. & Deteceda/nM & Added/nM & Found/nM & Recovery, \% \\
\hline 1 & ND & 5.00 & 5.03 & 100.6 \\
2 & ND & 5.00 & 5.12 & 102.4 \\
3 & ND & 10.00 & 9.89 & 98.9 \\
4 & ND & 20.00 & 19.49 & 97.4 \\
5 & $1.7( \pm 2.6 \%)$ & 5.00 & 6.61 & 98.2 \\
\hline
\end{tabular}

a. The average of five determinations.

more target molecules to form duplex DNA. So 15 bp sequences of DNA were chosen.

\section{Applications}

The applications of the proposed method were evaluated for the determination of $\mathrm{Hg}^{2+}$ in tap-water samples. The samples were collected after discharging the tap water for about $20 \mathrm{~min}$. After boiling for $5 \mathrm{~min}$ to remove chlorine, the water samples were spiked with $\mathrm{Hg}^{2+}$ at different concentration levels, which were prepared on the basis of possible metal ion concentrations in the environmental water, and then analyzed with the proposed method. The results of concerning determination of $\mathrm{Hg}^{2+}$ concentrations in tap water are given in Table 1. The accuracy of the assay was also tested by performing a recovery experiment. From Table 1, one can observe satisfactory results. It seems to be useful for applications to real samples.

\section{Conclusion}

A new highly selective ECL biosensor for the detection of $\mathrm{Hg}^{2+}$ based on the interaction between $\mathrm{T}$ and $\mathrm{Hg}^{2+}$ and the ruthenium complex as a signal-producing compound has been designed. This work demonstrates that the ECL biosensor designed by combining a T-rich DNA probe strongly binding to $\mathrm{Hg}^{2+}$ gives a highly sensitive ECL technique that can be used to determine $\mathrm{Hg}^{2+}$. The ECL biosensor presents relatively sensitive $\mathrm{Hg}^{2+}$ detection and good selectivity for discriminating $\mathrm{Hg}^{2+}$ from other metal ions. The developed biosensor provides a promising strategy for the detection of metal ions.

\section{References}

1. Q. R. Wang, D. Kim, D. D. Dionysiou, G. A. Sorial, and D. Timberlake, Environ. Pollut., 2004, 131, 323.

2. A. H. Stern, Environ. Res., 2005, 98, 133.

3. F. M. M. Morel, A. M. L. Kraepiel, and M. Amyot, Annu. Rev. Ecol. Syst., 1998, 29, 543.

4. I. Onyido, A. R. Norris, and E. Buncel, Chem. Rev., 2004, 104, 5911.
5. J. Gomez-Ariza, F. Lorenzo, and T. Garcia-Barrera, Anal. Bioanal. Chem., 2005, 382, 485.

6. F. X. Han, W. Dean Patterson, Y. J. Xia, B. B. Maruthi Sridhar, and Y. Su, Water, Air, Soil Pollut., 2006, 170, 161.

7. B. Fong, W. Mei, T. S. Siu, J. Lee, K. Sai, and S. Tam, J. Anal. Toxicol., 2007, 31, 281.

8. W. Geng, T. Nakajima, H. Takanashi, and A. Ohki, J. Hazard. Mater., 2008, 154, 325.

9. Y. L. Yu, Z. Du, and J. H. Wang, J. Anal. At. Spectrom., 2007, 22, 650 .

10. G. Cabello-Carramolino and M. D. Prtit-Dominguez, Anal. Chim. Acta, 2008, 614, 103.

11. W. Yantasee, Y. Lin, T. S. Zemanian, and G. E. Fryxell, Analyst, 2003, 128, 467.

12. A. H. Miguel and C. M. Jankowski, Anal. Chem., 1974, 46, 1832.

13. Y. Bonfil, M. Brand, and E. Kirowa-Eisner, Anal. Chim. Acta, 2000, 424, 65.

14. M. Lerchi, E. Ritter, W. Simon, E. Pretsch, D. A. Chowdhury, and S. Kamata, Anal. Chem., 1994, 66, 1713.

15. C. Sanchez-Pedre, J. A. Ortu, M. I. Albero, M. S. Garcia, and M. V. Valero, Anal. Chim. Acta, 2000, 414, 195.

16. C. W. Liu, Y. T. Hsieh, C. C. Huang, Z. H. Lin, and H. T. Chang, Chem. Commun., 2008, 19, 2242.

17. J. K. Wu, L. K. Li, B. J. Shen, G. F. Cheng, P. G. He, and Y. Z. Fang, Electroanalysis, 2010, 22, 479, and references therein.

18. Z. D. Liu, Y. F. Li, J. Ling, and C. Z. Huang, Environ. Sci. Technol., 2009, 43, 5022.

19. W. Miao, Chem. Rev., 2008, 108, 2506.

20. R. D. Gerardi, N. W. Barnett, and S. W. Lewis, Anal. Chim. Acta, 1999, 378, 1.

21. K. A. Fahnrich, M. Pravda, and G. G. Guilbault, Talanta, 2001, 54, 531.

22. X. B. Yin, S. J. Dong, and E. K. Wang, Trends Anal. Chem., 2004, 23, 432.

23. A. W. Knight, Trends Anal. Chem., 1999, 18, 47.

24. H. L. Qi and C. X. Zhang, Anal. Chim. Acta, 2004, 501, 31.

25. H. Wang, C. X. Zhang, Y. Li, and H. L. Qi, Anal. Chim. Acta, 2006, 575, 205.

26. J. G. Bruno and J. L. Kiel, Biosens. Bioelectron., 1999, 14, 457.

27. J. G. Bruno and J. L. Kiel, Biotechniques, 2002, 32, 178.

28. T. Li, B. L. Li, and S. J. Dong, Chem. Eur. J., 2007, 13, 6718.

29. K. Kalyanasundaram, Md. K. Nazeeruddin, M. Gratzel, G. Viscardi, P. Savarino, and E. Barni, Inorg. Chim. Acta, 1992, $198-200,831$.

30. E. Terpetschnig, H. Szmacinski, H. Malak, and J. R. Lakowicz, Biophys. J., 1995, 68, 342.

31. T. Shimidzu, T. Iyoda, and K. Izaki, J. Phys. Chem., 1985, 89,642 .

32. J. Zhang, H. L. Qi, Y. Li, J. Yang, Q. Gao, and C. X. Zhang, Anal. Chem., 2008, 80, 2888. 